\title{
Effects of Nanometakaolin on the Physico-Chemical Characteristics of Various Blended Cement Pastes
}

\section{Doaa A. Ahmed, Maha R. Mohamed and Aya allah M. Ebrahim*}

\author{
Chemistry Dep., Faculty of Girls, Ain Shams University, Cairo, Egypt.
}

\begin{abstract}
The physico-chemical characteristics of various blended cement pastes are studied in presence of nanometakaolin $(2,4,6$ and $8 \%)$ and in absence and presence of some industrial wastes such as ground clay bricks, cement kiln dust and silica fume. These characteristics are investigated at different hydration times (1-180 days) via determination of the compressive strength, total porosity and chemically combined water content. In addition, the phase composition of the formed hydrates is investigated through X-ray diffraction analysis. The IR spectra of hardened cement pastes are also recorded. The results indicate that the presence of nanometakaolin accelerates the hydration of the pastes which exhibit higher compressive strength than the neat ordinary Portland cement, and improves some other characteristics of the different pastes.
\end{abstract}

Keywords: Nanometakaolin, Blended cement, Pysico-chemical characteristics of blended cement.

\section{Introduction}

Nanotechnology is one of the most promising areas of science. The development in nanoscience can have a great impact on the field of construction materials. Ordinary Portland cement (OPC), is obviously the product with great, but not completely explored potential. It is known that chemical activation is an effective way to improve the strength of cementbased materials. Many trials are performed to partially replace OPC by some other cheaper additives which result as by-products from some industries and may improve the cementpastes characteristics. Examples of these materials are metakaolin, nanometakaolin, ground clay bricks

Corresponding author: Email: Ayaallah.mahmoud@yahoo.com 
cement kiln dust and silica fume. These by-products may also be used to reduce costs, energy and pollution.

The effect of these additives on the mechanical and chemical properties of plain cement pastes is investigated and reported in the literature.

Metakaolin (MK), a valuable pozzolanic material, can react with the lime liberated from the hydration of OPC forming calcium silicate hydrate. It is a thermally activated aluminosilicate material obtained by calcining kaolin clay within the temperature range of 700- $850^{\circ} \mathrm{C}$ [Ambroise, 1994, Sabir et al., 1996 and Shebl et al., 2009]. MK, when ground in a high speed grinding mill, is reduced to the nano scale (NMK) [Aiswarya et al., 2013]. An increase in compressive, flexural strength and improvement of mechanical properties of mortars containing nano-particles are observed by Sobolev et al. (2006).

Ground clay bricks (GCB), known as homra, is a solid material produced from the manufacture of clay bricks. In Egypt about $5-10 \%$ of homra is a waste product. It is constituted mainly of silica quartz, aluminosilicates, anhydrite and hematite. Therefore, it acts as a good pozzolanic material which shows a slow rate and heat of hydration. Homra also shows good resistance to aggressive media such as sulphate and chlorides [Heikal et al., 2000 and Heikal and El-Didamony, 1999]. Bektas et al. (2008 and 2009) showed that when it is finely ground, clay brick, obtained from demolished masonry, can be recycled as a pozzolanic cementitious material in concrete. It was found that $10 \%$ replacement of cement by GCB gave the highest compressive strength [Kartini, 2012].

Cement kiln dust (CKD), a by-pass dust, is generated in large quantities during the production of PC. It is a fine powdery material of gray to tan in color [similar in appearance to $\mathrm{OPC}$ ], highly alkaline powder and relatively uniform in size. Al-Harthy et al. (2003) reported that there was generally a decrease in compressive strength with an increase in CKD replacement for cement. Pavia and Regan (2010) observed that the compressive strength increases with the CKD content with the exception of 5\% CKD mortar.

Silica fume (SF) is an amorphous mineral material composed of extremely small and chemically active particles of $\mathrm{SiO}_{2}$ that appear as a by-product in silicon or ferrosilicon industries. More than $95 \%$ of SF particles are finer than $1 \mu \mathrm{m}$. Almusallam et al. (2004) and 
Mazloom et al. (2004) concluded that the higher compressive strength noted in the SF cement concrete, compared to plain cement concrete, may be attributed to the reaction of the SF with calcium hydroxide liberated during the hydration of cement. Rang et al. (2014) indicated that the hydration process could be accelerated at the beginning by addition of SF, and fly ash. However, retarded hydration may occur mainly in the dormant and acceleration periods.

So the present study aims to investigating the effect of the presence of NMK on the mechanical properties and microstructure of some different blended-Portland cement pastes as will be mentioned below.

\section{Materials and Methods}

\section{1. Materials}

The materials used in this investigation are: ordinary Portland cement supplied from Helwan cement factory with blain surface area of $2945 \mathrm{~cm}^{2} / \mathrm{g}$, nano metakaolin prepared from kaolinite by burning at $800^{\circ} \mathrm{C}$ for 2 hours, ground clay bricks, cement kiln dust and silica fume (SF) obtained from Toura factory and El Nasr Pharmaceutical chemical company, respectively. The chemical analysis of the utilized materials are given in Table (1),

\section{2. Preparation of the cement pastes}

Cement and the different additives are first mixed in the dry state to attain complete homogeneity. The pastes are prepared using $W / S$ ratio $=0.27$. Table (2) shows the designation and the percentage composition of the prepared mixes. After complete mixing, the resultant pastes are molded into specimens by using one-inch cubic moulds. The moulds containing the pastes are cured in $100 \%$ relative humidity for 24 hours, then the specimens are removed from the moulds and cured under water for different hydration periods, namely; 3, 7, 28, 90 and 180 days. Some of the hardened cement pastes are tested by XRD $(\mathrm{Cu} \mathrm{K \alpha})$ and FT-IR spectra to investigate their structure. Also, the compressive strength, porosity and combined water content are determined for some chosen samples. 


\begin{tabular}{|c|c|c|c|c|c|c|c|c|c|c|c|c|c|}
\hline \multirow{2}{*}{ Materials } & \multicolumn{9}{|c|}{ Oxide (\%) } & \multirow{2}{*}{$\begin{array}{l}\text { Ignition } \\
\text { Loss }\end{array}$} & \multirow{2}{*}{$\begin{array}{l}\text { Insoluble } \\
\text { residue }\end{array}$} & \multirow{2}{*}{ SM } & \multirow{2}{*}{ AM } \\
\hline & $\mathrm{SiO}_{2}$ & $\mathrm{Al}_{2} \mathrm{O}_{3}$ & $\mathrm{Fe}_{2} \mathrm{O}_{3}$ & $\mathrm{CaO}$ & $\mathrm{NaO}$ & $\mathrm{K}_{2} \mathrm{O}$ & $\mathrm{Cl}$ & MgO & $\mathrm{SO}_{3}$ & & & & \\
\hline OPC & 20.1 & 4.72 & 3.94 & 62.98 & -- & 0.27 & 0.04 & 1.77 & 2.67 & 2.95 & 0.91 & -- & -- \\
\hline NMK & 61.24 & 20.89 & 6.38 & 0.16 & 1.61 & 0.71 & $\overline{--}$ & 0.38 & 0.17 & 13.62 & -- & -- & -- \\
\hline$\overline{\mathrm{GCB}}$ & 74.8 & 14.03 & 5.04 & 1.25 & -- & -- & -- & 1.3 & 0.8 & 2.58 & -- & -- & -- \\
\hline CKD & 12.11 & 3.05 & 1.92 & 46.86 & 0.29 & 4.44 & 4.15 & 2.04 & 10.89 & 7.31 & -- & 2.44 & 1.61 \\
\hline SF & 96.8 & 0.2 & 0.4 & 0.16 & -- & 0.03 & -- & 0.09 & 0.3 & 1.98 & -- & -- & -- \\
\hline
\end{tabular}

Table (1): The chemical composition of the used materials.

\begin{tabular}{|c|c|c|c|c|c|}
\hline \multirow{2}{*}{ Mixes } & \multicolumn{5}{|c|}{ Composition \% } \\
\cline { 2 - 6 } & OPC & NMK & GCB & CKD \\
\hline MI & 100 & 0 & 0 & 0 & 0 \\
\hline MIB & 98 & 2 & 0 & 0 & 0 \\
\hline MIC & 96 & 4 & 0 & 0 & 0 \\
\hline MID & 92 & 6 & 0 & 0 & 0 \\
\hline MIIA & 80 & 2 & 10 & 8 & 0 \\
\hline MIIB & 70 & 4 & 20 & 6 & 0 \\
\hline MIIC & 60 & 6 & 30 & 4 & 0 \\
\hline MIID & 50 & 8 & 40 & 2 & 0 \\
\hline MIIIA & 80 & 2 & 10 & 0 & 0 \\
\hline MIIIB & 70 & 4 & 20 & 0 & 0 \\
\hline MIIIC & 60 & 6 & 30 & 0 & 0 \\
\hline MIIID & 50 & 8 & 40 & 0 & 0 \\
\hline
\end{tabular}

Table (2): The designation and composition of the prepared mixes.

\section{Results and discussion}

\section{1. Compressive strength}

The values of compressive strength of the control mix $\left(\mathrm{M}_{\mathrm{o}}\right)$ and blended cement mixes containing various percentages of nanometakaolin (MIA $\rightarrow$ MID) are given in Table (3). Generally, it is found that the compressive strength increases on increasing the percentage of NMK up to $8 \%$ at all hydration ages. Similar finding are reported by Morsy et al. (2008, 2011 and 2012) and by Petal (2012). Also Aiswarya et al. (2013) found that partial replacement of cement with NMK (2-20\%) has a greater influence on the strength of concrete 
than control concrete. Hence, the obtained results are explained on the basis that ultra-fine particles of NMK may fill the voids in cement pastes, thus making its microstructure somewhat denser. Also, the pozzolanic reaction of NMK with the free lime and calcium hydroxide (released during the hydration process) may produce excess calcium silicate hydrate that gets deposited in the pore system. This deposited Ca-silicate hydrate may cause the improvement of the compressive strength.

\begin{tabular}{|l|l|l|l|l|l|l|}
\hline \multirow{2}{*}{ Mix } & \multicolumn{6}{|c|}{ Compressive strength (Kg/cm $\left.{ }^{2}\right)$} \\
\cline { 2 - 7 } & 1 day & 3 days & 7 days & 28 days & 90 days & 180 days \\
\hline Mo & 158.1 & 213.4 & 260.9 & 332 & 379.4 & 424.5 \\
\hline MIA & 189.7 & 237.2 & 316.2 & 419 & 442.7 & 474.3 \\
\hline MIB & 213.4 & 268.8 & 363.6 & 442.7 & 474.3 & 490.1 \\
\hline MIC & 237.2 & 284.6 & 395.3 & 474.3 & 505.9 & 545.4 \\
\hline MID & 268.8 & 316.2 & 411.1 & 505.9 & 537.5 & 584.9 \\
\hline
\end{tabular}

Table (3): Compressive strength at different hydration ages of the cement mixes containing NMK only.

Tables ( $4 \& 5$ ) show the change of the compressive strength of the cement mixes at different hydration ages on adding different percentages of GCB (10-40\%) in presence of very small percentages (2-8\%) of either CKD or SF, respectively. It can be shown that the increase in the compressive strength of the cement pastes reaches its optimum value at $4 \%$ NMK, 20\% GCB and 6\% CKD or SF, and hence 70\% OPC. Then the values of the compressive strength are decreased as the percentage of GCB increases and those of CKD or SF are decreased. It is to be noticed also that the optimum compressive strength value is almost the same on using either CKD or SF. The increase in the compressive strength at 10 and $20 \%$ of GCB may be due to the pozzolanic reaction of GCB and SF. However, the decrease in the strength at higher GCB concentration may be attributed to two factors; the dilution of OPC resulting in the decrease of $C_{3} S$ and $\beta-C_{2} S$ phases in the blended cement pastes and agglomeration of GCB around the OPC grains thus hindering the hydration process. Accordingly, the amount of hydration products is decreased leading to a decrease in the compressive strength as also reported by Kartini (2012). The slight increase in the 
compressive strength values in presence of SF than in case of CKD may be due to the pozzolanic reaction of SF with the librated lime leading to more production of ( the binder agent) CSH [El Alfi, 2004].

\begin{tabular}{|c|c|c|c|c|c|c|}
\hline \multirow{2}{*}{ Mix } & \multicolumn{6}{|c|}{ Compressive strength (Kg/cm ${ }^{2}$ ) } \\
\cline { 2 - 7 } & 1 day & 3 days & 7 days & 28 days & 90 days & 180 days \\
\hline Mo & 158.1 & 213.4 & 260.9 & 332 & 379.4 & 424.5 \\
\hline MIIA & 181.8 & 230 & 268.8 & 347.8 & 395.3 & 439 \\
\hline MIIB & 189.7 & 258 & 297 & 371.5 & 424 & 461 \\
\hline MIIC & 160 & 200 & 250 & 311 & 359 & 391 \\
\hline MIID & 145 & 176 & 227 & 291 & 346 & 360.6 \\
\hline
\end{tabular}

Table (4): Compressive strength at different hydration ages of the cement mixes containing NMK, GCB and CKD.

\begin{tabular}{|c|c|c|c|c|c|c|}
\hline \multirow{2}{*}{ Mix } & \multicolumn{6}{|c|}{ Compressive Strength $\left(\mathrm{Kg} / \mathrm{cm}^{2}\right)$} \\
\hline & 1 day & 3 days & 7 days & 28 days & 90 days & 180 days \\
\hline Mo & 158.1 & 213.4 & 260.9 & 332 & 379.4 & 424.5 \\
\hline MIIIA & 189.7 & 253 & 284.6 & 363.6 & 400 & 441.1 \\
\hline MIIIB & 197.6 & 268.8 & 300.4 & 379.4 & 420 & 465.3 \\
\hline MIIIC & 170 & 225.7 & 272 & 345.3 & 389.9 & 432.6 \\
\hline MIIID & 154 & 200.1 & 250.7 & 315 & 363 & 395.3 \\
\hline
\end{tabular}

Table (5): Compressive strength at different hydration ages of the cement mixes containing NMK, GCB and SF.

\section{2 . The porosity}

Table (6) shows the total porosity of all mixes at the two hydration ages 7 and 180 days as representative examples. It is obvious that the total porosity of all the investigated mixes decreases with increasing the hydration ages. This may be due to the progress of the hydration reaction and formation of more hydration products $(\mathrm{CSH})$ which fill the pores. 
Such results agree with those of the compressive strength. Table (6) also shows that the values of porosity decrease in presence of CKD and SF compared to that of the control mix. This can be explained as being due to the retardation effect caused by filling the pores by these admixtures.

\begin{tabular}{|c|c|c|c|c|c|c|c|c|c|c|c|c|c|}
\hline \multirow{2}{*}{$\begin{array}{c}\text { Hydration } \\
\text { Time }\end{array}$} & \multicolumn{90}{|c|}{ Cement Mixes } \\
\cline { 2 - 12 } & Mo & MIA & MIB & MIC & MID & MIIA & MIIB & MIIC & MIID & MIIIA & MIIIB & MIIIC & MIIID \\
\hline 7 days & 33 & 28.8 & 28.2 & 27.8 & 27 & 32.3 & 31.9 & 33.4 & 33.8 & 29 & 28.5 & 29.4 & 30.1 \\
\hline 180 days & 31 & 26.1 & 24.2 & 23.8 & 22.9 & 28.8 & 28 & 29.1 & 30.9 & 26 & 25 & 25.4 & 26.6 \\
\hline
\end{tabular}

Table (6): The porosity values of blended cement pastes at the hydration ages 7 and 180 days.

\section{3. The chemically combined water}

The values of the combined water content are found to increase with increasing hydration time for all the blended cement pastes as shown in Tables $(7,8 \& 9)$. This is due to the continuous hydration and accumulation of the hydration products. Table (7) indicates that the addition of the different percentages of NMK $(2,4,6$ and $8 \%)$ increases the combined water content at all the hydration ages compared to that of the control mix (Mo). A similar conclusion is reported by Abd El-Aleem et al. (2005). However, the presence of the other additives GCB/CKD and GCB/SF (Table 8 and 9, respectively) lowers the values of the combined water content relative to those of Mo and MIA-MID mixes. This decrease in the values becomes more considerable as the percentages of GCB is increased from 10 to $40 \%$. This may be accounted for the high hydraulic properties of cement phases rather than other additives which are characterized by low or no hydraulic properties [Shoaib et al., 1999]. Also, it has been shown recently that the increased hydration products due to pozzolanic reactions of metakaolin result in reduced values of water sorptivity [Aly et al., 2011].

Mix

Combined water (\%) 


\begin{tabular}{|c|c|c|c|c|c|c|}
\hline & $\mathbf{1}$ day & $\mathbf{3}$ days & $\mathbf{7}$ days & $\mathbf{2 8}$ days & $\mathbf{9 0}$ days & $\mathbf{1 8 0}$ days \\
\hline Mo & 9.8 & 12.7 & 14.2 & 15.8 & 18.1 & 19.4 \\
\hline MIA & 10.0 & 13.0 & 15.0 & 17.0 & 18.9 & 19.8 \\
\hline MIB & 10.5 & 13.5 & 15.6 & 17.7 & 19.5 & 20.8 \\
\hline MIC & 10.9 & 14.0 & 16.3 & 18.2 & 20.1 & 21.7 \\
\hline MID & 11.3 & 14.4 & 17.0 & 18.9 & 20.7 & 22.4 \\
\hline
\end{tabular}

Table (7): Combined water at different hydration ages of the cement mixes containing NMK only.

\begin{tabular}{|c|c|c|c|c|c|c|}
\hline \multirow{2}{*}{ Mix } & \multicolumn{7}{|c|}{ Combined Water (\%) } \\
\cline { 2 - 7 } & $\mathbf{1}$ day & $\mathbf{3}$ days & $\mathbf{7}$ days & $\mathbf{2 8}$ days & $\mathbf{9 0}$ days & $\mathbf{1 8 0}$ days \\
\hline Mo & 9.8 & 12.7 & 14.2 & 15.8 & 18.1 & 19.4 \\
\hline MIIA & 8.5 & 11.5 & 13.1 & 14.4 & 16.6 & 18.0 \\
\hline MIIB & 7.9 & 10.6 & 12.4 & 13.6 & 15.9 & 17.2 \\
\hline MIIC & 6.8 & 9.3 & 11.5 & 12.9 & 15.0 & 16.4 \\
\hline MIID & 5.8 & 8.5 & 10.3 & 11.7 & 14.1 & 15.2 \\
\hline
\end{tabular}

Table (8): Combined water at different hydration ages of the cement mixes containing NMK, GCB and CKD.

\begin{tabular}{|c|c|c|c|c|c|c|}
\hline \multirow{2}{*}{ Mix } & \multicolumn{7}{|c|}{ Combined water (\%) } \\
\cline { 2 - 7 } & $\mathbf{1}$ day & $\mathbf{3}$ days & $\mathbf{7}$ days & $\mathbf{2 8}$ days & $\mathbf{9 0}$ days & $\mathbf{1 8 0}$ days \\
\hline Mo & 9.8 & 12.7 & 14.2 & 15.8 & 18.1 & 19.4 \\
\hline MIIIA & 9.2 & 12.0 & 13.7 & 15.0 & 17.2 & 18.5 \\
\hline MIIIB & 8.5 & 11.3 & 13.0 & 14.4 & 16.5 & 17.9 \\
\hline MIIIC & 7.4 & 10.5 & 12.1 & 13.7 & 15.6 & 17.0 \\
\hline MIIID & 6.3 & 9.2 & 11.0 & 12.5 & 14.7 & 16.1 \\
\hline
\end{tabular}

Table (9): Combined water at different hydration ages of the cement mixes containing NMK, GCB and SF.

\section{4. Phase composition:}

The X-ray diffraction ( $\mathrm{Cu} \mathrm{K \alpha}$ ) partterns obtained after 90 days hydration of the control mix (Mo) and in the presence of 2, 4, 6 and 8\% NMK (MIA-MID, respectively) are shown in Fig. (1). It can be observed that, the intensity of the peaks characteristic of calcium hydroxide $(\mathrm{CH})$ is gradually decreased as NMK-percentage is increased. This may be due to the high pozzolanic activity of NMK. 
The diffraction patterns of the cement pastes containing 2, 4, 6 and $8 \%$ of CKD and SF in addition to the considered percentages of NMK and GCB (MIIA-MIID and MIIIA-MIIID, respectively) after 90 days hydration are given in Figs. ( 2 and 3, respectively). The intensity of the peaks characteristic of $\mathrm{CH}$ is found to decrease in case of the first two mixes (MIIA, MIIIA and MIIB, MIIIB) . Then, the peak's intenisties increase in the other two mixes (MIIC, MIIIC and MIID, MIIID). Also, it can be noticed that the intensities of the $\mathrm{CH}$ peaks in presence of CKD are higher than those in presence of SF. This can be attributted to the higher pozzolnic activity of SF than that of CKD.

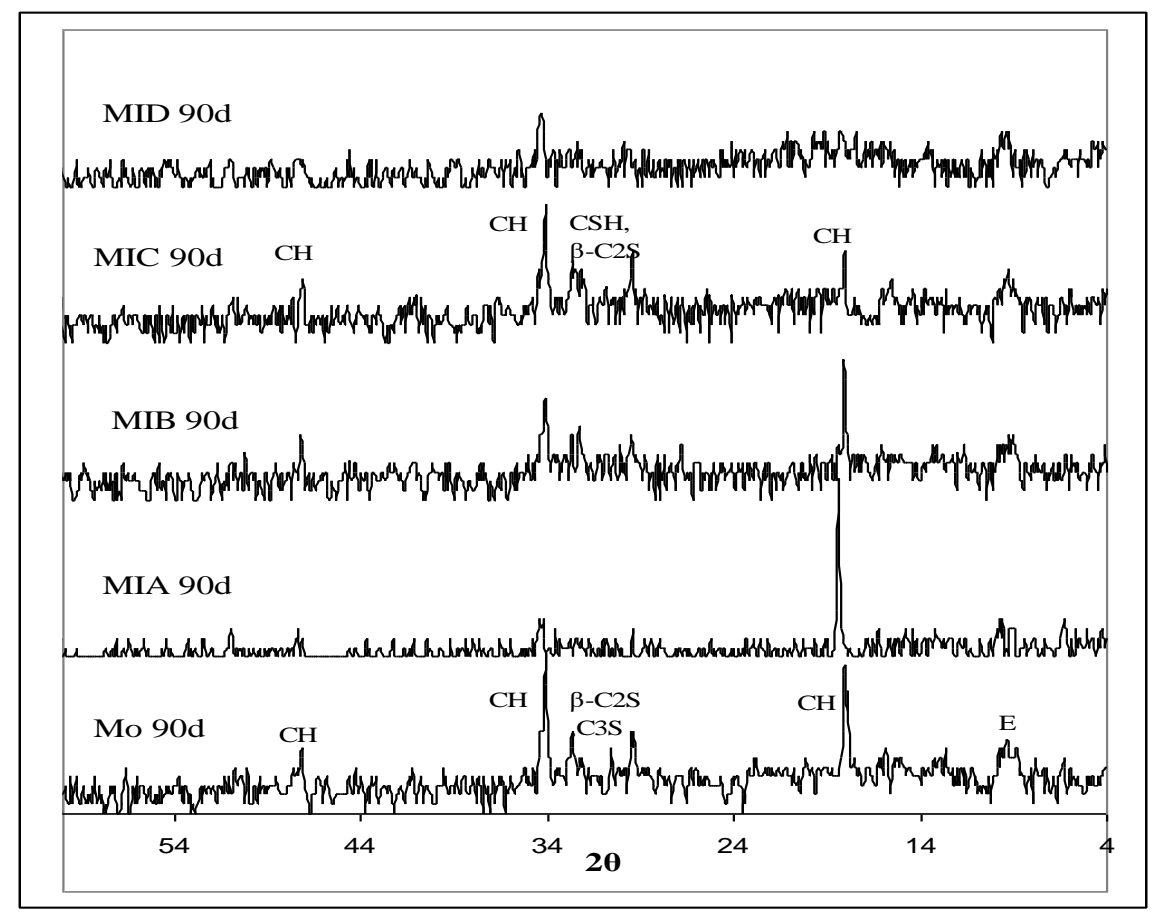

Figure (1): X-ray diffraction patterns of the control mix Mo and MIA-MID mixes at 90 days hydration time. 


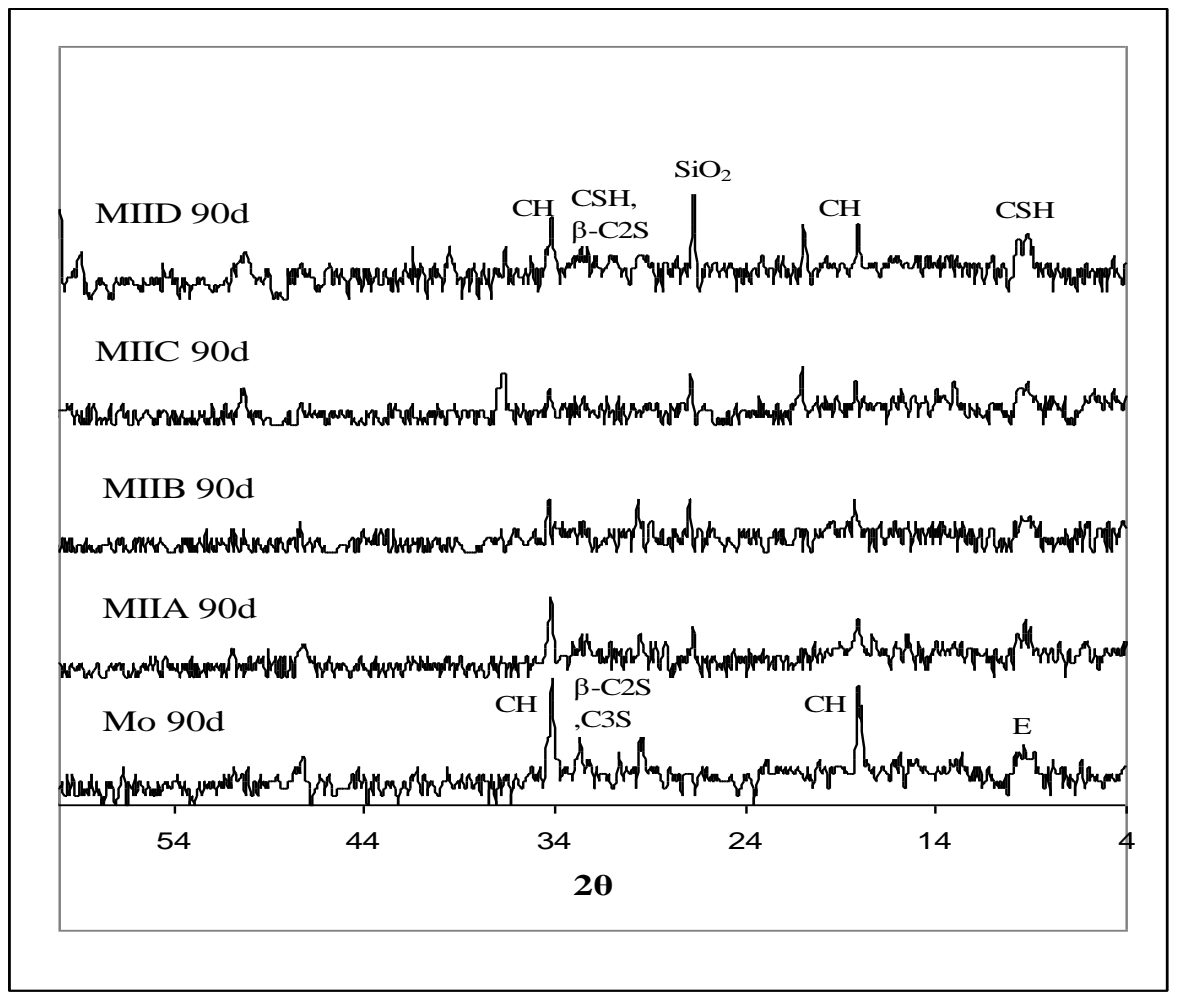

Figure (2): X-ray diffraction patterns of the control mix Mo and MIIA-MIID mixes at 90 days hydration time.

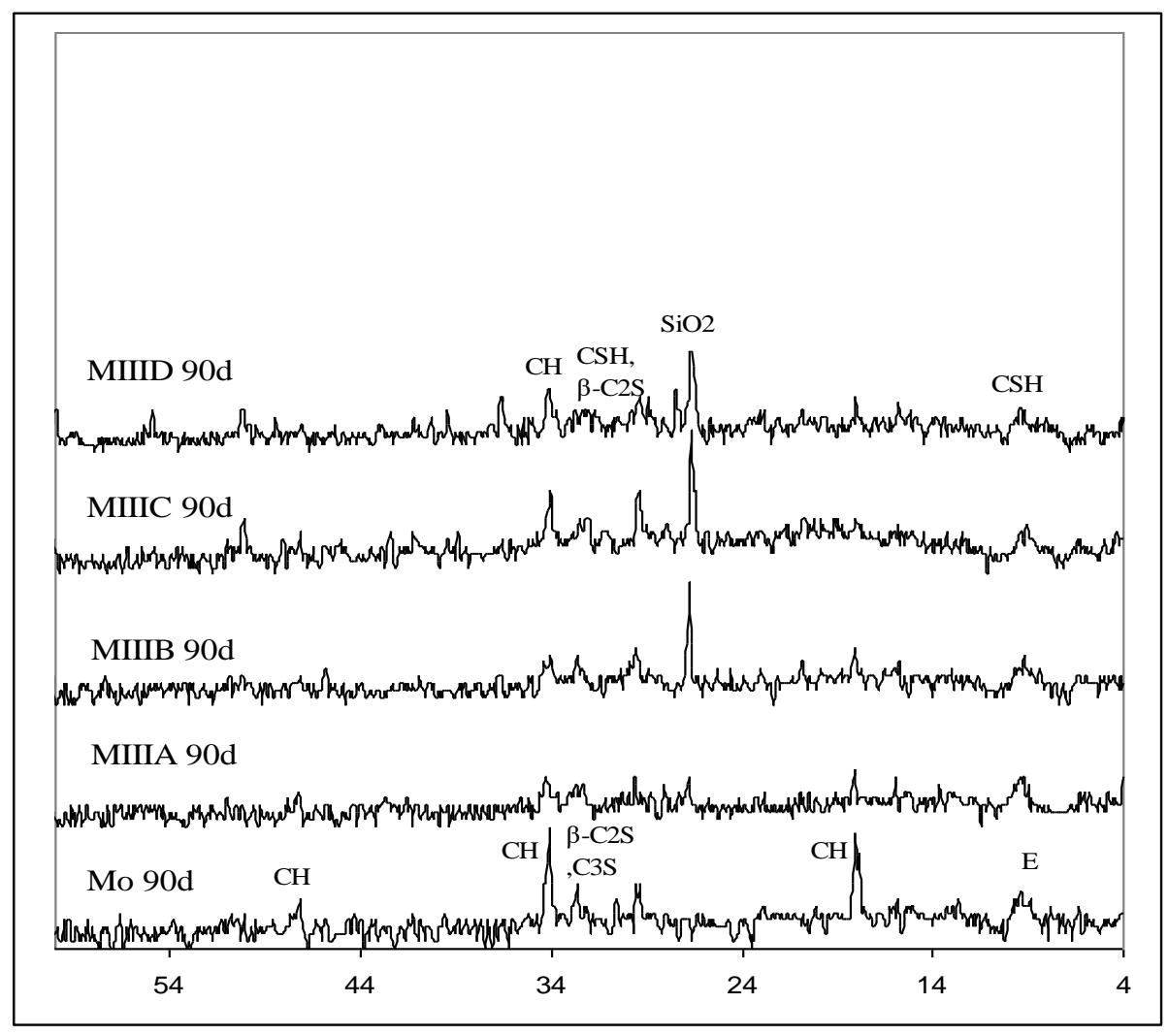


Figure (3): X-ray diffraction patterns of the control mix Mo and MIIIA-MIIID mixes at 90 days hydration time.

\section{6. Infrared Spectroscopy (IR)}

FT-IR technique is used to investigate the IR spectra of the cement pastes in presence of NMK and the additives: GCB, CKD and SF. The IR spectra of some of the tested cement mixes, namely Mo, MIA, MID, MIIA, MIID, MIIIA and MIIID are presented in Figs. (5 and 6). Absorption bands at 3641- $3642 \mathrm{~nm}$ due to the stretching vibration of the $(\mathrm{OH})$ group of $\mathrm{Ca}(\mathrm{OH})_{2}$ in additiom to strong bands at 3450 and $1650 \mathrm{~nm}$ attributed to $-\mathrm{OH}$ or $\mathrm{H}_{2} \mathrm{O}$ stretching and bending vibrations, respectively, clearly appear in the spectra [Theophile, 2012 and YImen et al., 2009]. The bands at 1424, 875 and $712 \mathrm{~nm}$ are attributed to $\dot{u}\left(\mathrm{CO}_{3}\right)$. The strong bands at 970 and $515 \mathrm{~nm}$ may be accounted for the ( $\mathrm{Si}-\mathrm{O})$ absorption bands of the C-S-H phase. Absorptions at 2360 and $2337 \mathrm{~nm}$ are supported to be due to the stretching vibration of $\dot{u}(\mathrm{Si}-\mathrm{H})$ of $\mathrm{C}-\mathrm{S}-\mathrm{H}$.

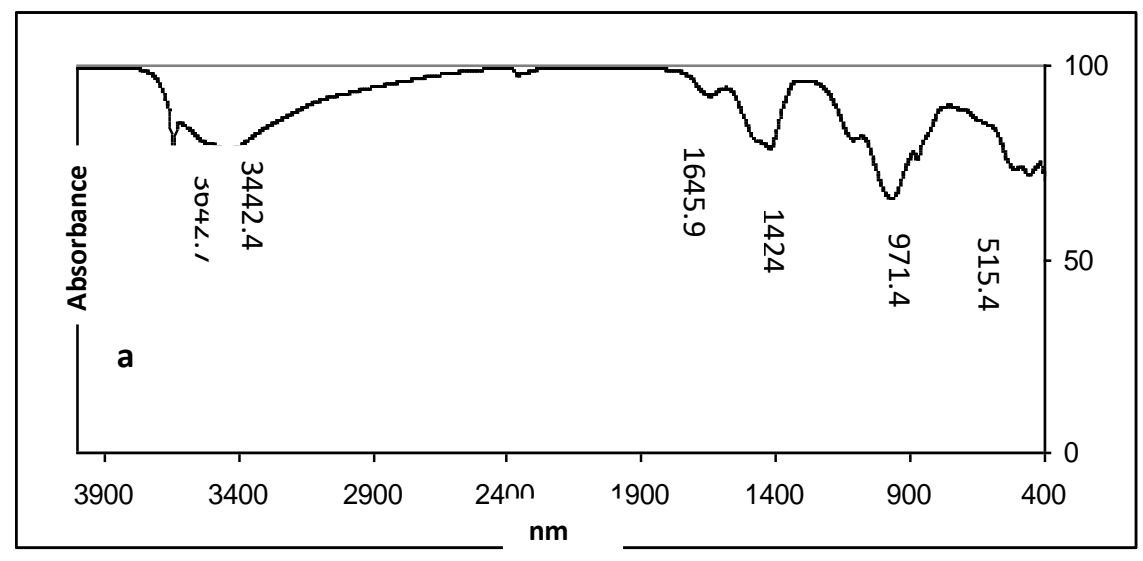

Figure (5 a): IR spectra for blank cement pastes hydrated for 90 days. 


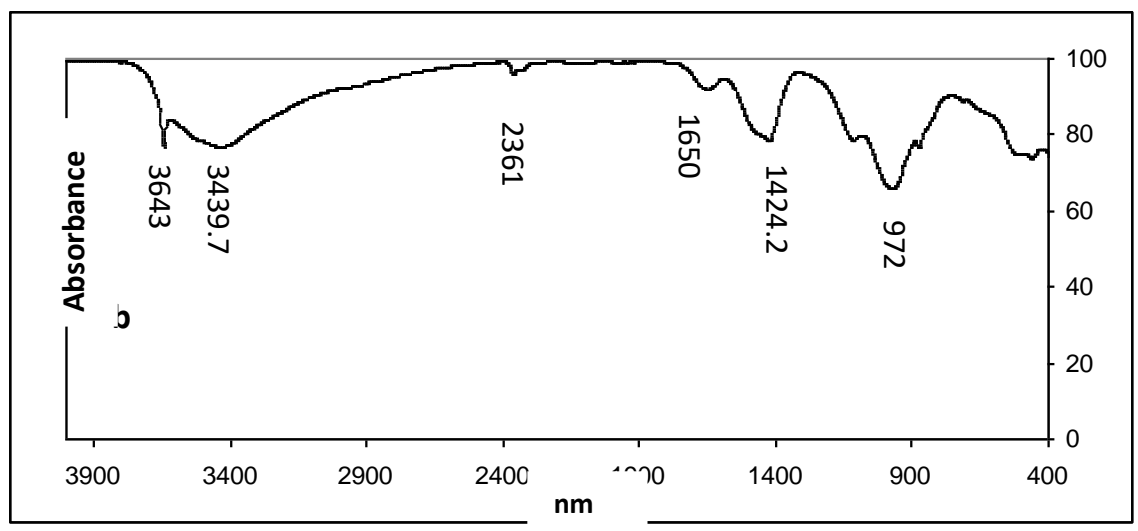

Figure (5b): IR spectra for blended cement paste MIA hydrated for 90 days.

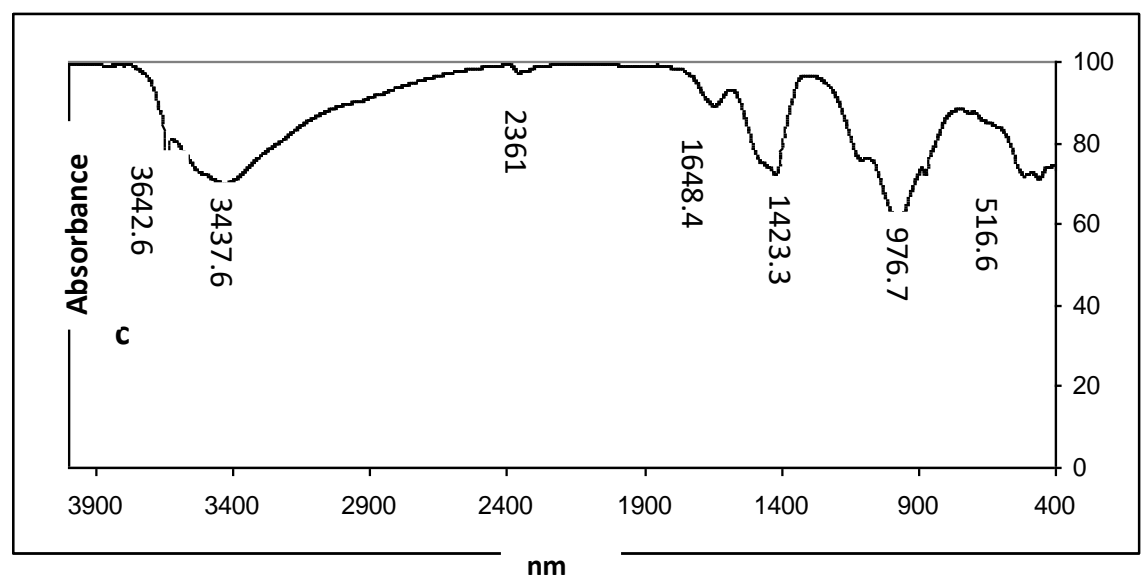

Figure (5c): IR spectra for blended cement paste MID hydrated for 90 days.

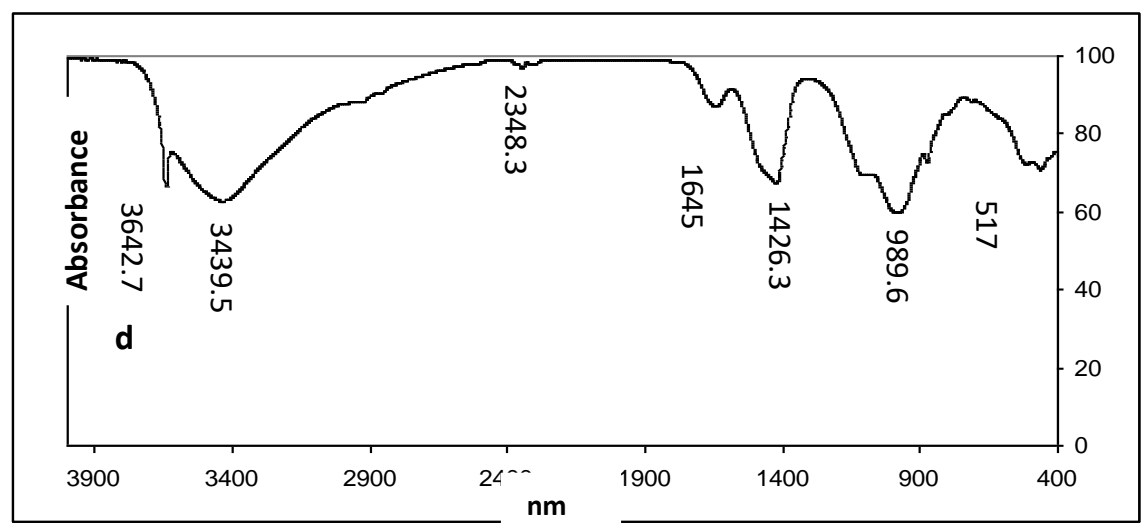

Figure (6d): IR spectra of blended cement paste MIIA hydrated for 90 days. 


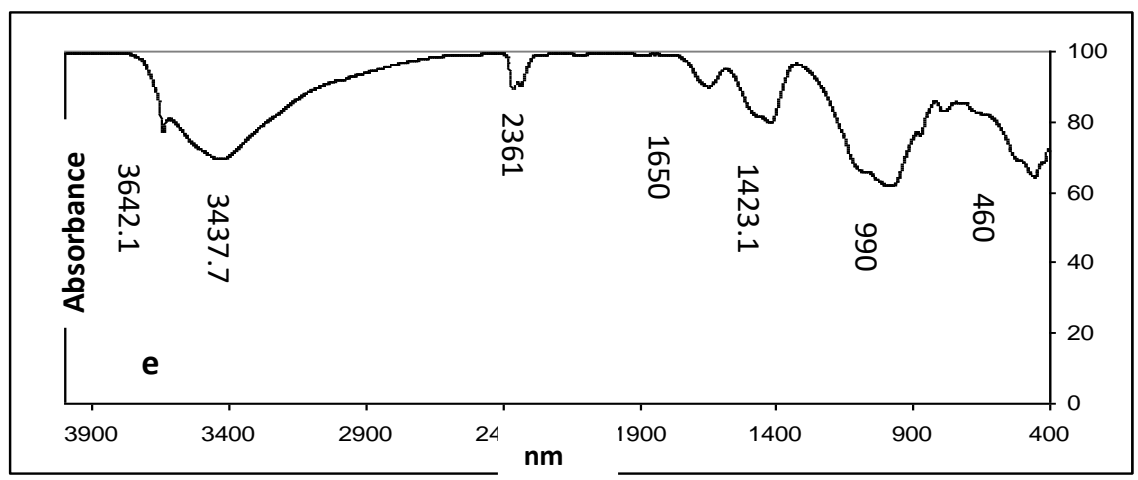

Figure (6e): IR spectra of blended cement paste MIID hydrated for 90 days.

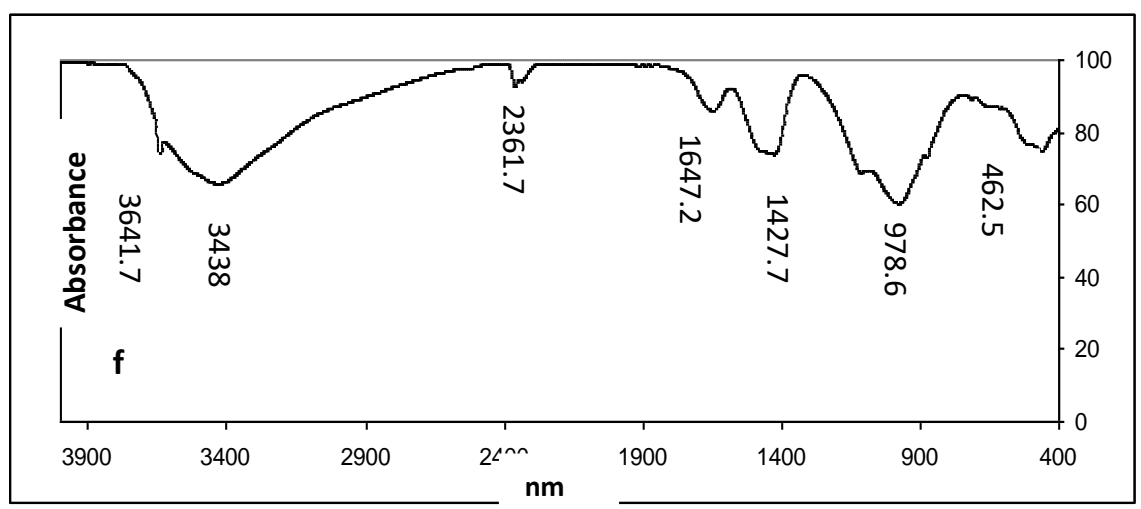

Figure (6f): IR spectra of blended cement paste MIIIA hydrated for 90 days.

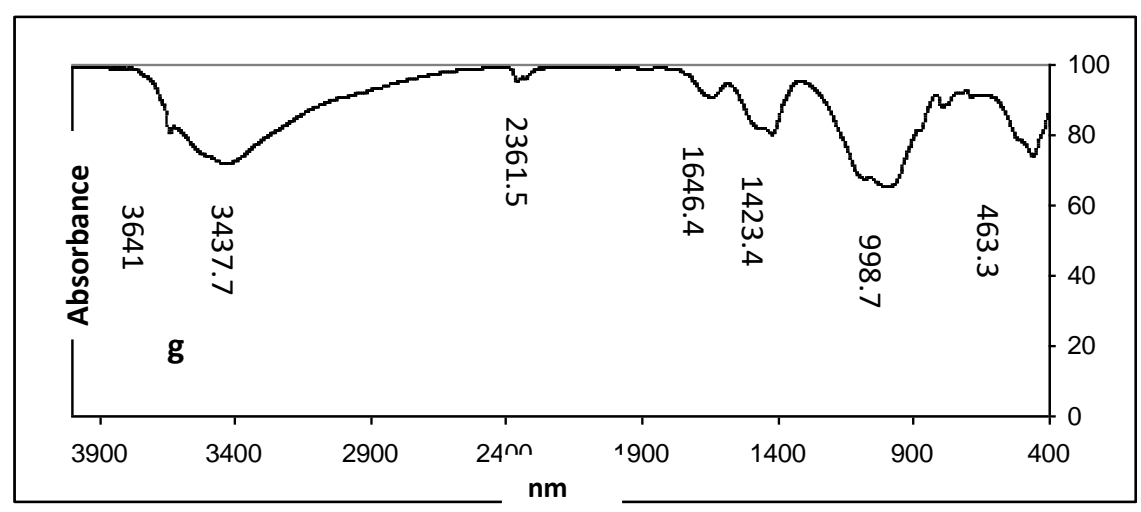

Figure (6g): IR spectra of blended cement paste MIIID hydrated for 90 days. 


\section{Conclusion}

From the above results, it can be concluded that:

- The compressive strength of all the blended cement mixes increases on increasing the hydration time, while, the combined water content for these mixes percentages decrease on increasing hydration time.

- The compressive strength of the blended cement pastes at all hydration times is increased on adding NMK.

- The blended OPC mixes with NMK show relatively lower values of total porosity compared to that of the control mix.

- The optimum value of the compressive strength is exhibited at $4 \% \mathrm{NMK}, 20 \%$ GCB and $6 \%$ SF or CKD.

\section{References}

Abd El-aleem S., Abd El-Aziz M. A., Heikel M., and El Didamony H., "Effect of cement kiln dust substitution on chemical and physical properties and compressive strength of Portland and slag cement", The Arabian Journal for Science and Engineering, 30(28), 263273 (2005).

Aiswarya S., Prince Arulraj G., and Anand N., "Experimental investigation on concrete containing nano-metakaolin.", Engin. Sci. and Techn., 3(1), 180-187(2013).

AlHarthy S., Ramzi T., and Faisal M., "Effect of cement kiln dust (CKD) on mortar and concrete mixtures.", Construction and Building Materials, (17), 353-360(2003).

Almusallam A. A., Beshr H., Maslehuddin M., and Al-Amoudi O. S. B., "Effect of silica fume on the mechanical properties of low quality coarse aggregate concrete.", Cement and Concrete Composites, 26(7), 891-900(2004).

Aly M., Hashmi M. S. J., Olabi A.G., Messeiry M., and Hussain A. I., "Effect of nano clay particles on mechanical, thermal and physical behavior of waste-glass cement mortars". Mater. Sci. and Engin. A, (528), 7991-7998(2011).

Ambroise J., Maximillen S., and Pera J., "Properties of metakaolin blended cements". Advanced Cement Materials, 1(4), 161-8(1994). 
Bektas F., Ceylan H., and Wang K., "Use of ground clay brick as pozzolanic material on concrete.", Department of Civil, Construction Environmental Engineering, 5(10), (2008). Bektas F., Wang K., and Ceylan H., "Effects of crushed clay brick aggregate on mortar durability.", Construction and Building Materials., 23(5), 1909-1914(2009).

El-Alfi E. A., Radwan A. M., and Abed El-aleem," Effect of limestone fillers and silica fume pozzolana on the characteristics of sulfate resistant cement pastes.", National Research Center, 48(1), 29-30 (2004).

Heikal M., "Effect of temperature on the physico-mechanical and mineralogical properties of Homra pozzolanic cement pastes", Cement and Concrete Research, 30 (11), 1835-1839 (2000).

Heikal M., and El- Didamony H.," Pozzolanic Activity of Homra with Lime" , Man. Sci.Bull., 26 (1), 79-95 (1999).

Kartini K., Rohaidah M. N., and Zuraini Z. A., "Performance of ground clay bricks as partial cement replacement in grade 30 concrete.", World Academy of Science, Engineering and Technology, (68), 362-365(2012).

Kinnaresh P., "The use of nanoclay as constructional material.", Intern. J. of Engin. Res. and Appl., 2(4), 1382-1386(2012).

Konsitantin S., Ismael F., Roman H., and Leticia M., "Nanomaterial and Nanotechnology of High-Performance Cement Composites.", Nanotechnology of Concrete: Recent Developments and Future Perspectives (2006).

Mazloom M., Ramezanianpour A. A., and Brooks J. J., "Effect of silica fume on mechanical properties of high-strength concrete", Cement and Concrete Composites, 26(4), 347-57 (2004).

Morsy M. S., Al sayed S. H., and Aqel M., "Effect of Nano-clay on mechanical properties and microstructure of ordinary Portland cement mortar.", Intern. J. of Civil and Eng., 10(1), 23-27(2008).

Morsy M. S., Alsayed S. H., and Aqel M., "Hybrid effect of nano tube and nano-clay on physico-mechanical properties of cement mortar". Construction and Building Materials, (25), 145-149(2011).

Morsy M. S., Al-Salloum Y. A., Abbas H., and Alsayed S. H., "Behavior of blended cement mortars containing nano-metakaolin at elevated temperatures.", Constr. and Build. Mater., (35), 900-905(2012). 
Pavia S., and Regan D., "Influence of cement kiln dust on the physical properties of calcium lime mortars.", Mater Struct, (43), 381-91(2010).

Rang Z. D., Sun W., Xiao H. J., and Wang W., "Effect of silica fume and fly ash on hydration and microstructure evolution of cement based composites at low water-binder ratios.", Construction and Building Materials, (51), 446-450 (2014).

Sabir B. B., Wild S., and Khatib J. M., "On the workability and strength development of metakaolin concrete". In: Dhir RK, Dyer TD, editors. Concrete for Environmental Enhancement and Protection. London, UK: E\&FN Spon. 651-6(1996).

Shebl S. S., Allie L., Morsy M. S., and Aglan H. A., "Mechanical behavior of activated nano silicate filled cement binders", J Master Sci, (44), 1600-1606(2009).

Shoaib M. M., Balaha M. M., and Abdel-Rahman A. G., "Influence of cement kiln dust substitution on the mechanical properties of concrete.", Cement and Concrete Research, (30), 371-377 (1999).

Theophanides theophile, "Infrared spectroscopy in the analysis of building and construction materials", Infrared spectroscopy- Material science, Engineering and Technology, 370-382 (2012).

Ylmen R., Jaglid V., Marie Stanari B., and Panas I., "Early hydration and setting of Portland cement monitored by IR, SEM and vicat. Technique", Cement and Concrete Research, (39), 433-439 (2009). 


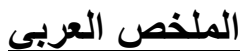

تأثير إضافة الناتو ميتا كاولين على الخصائص الفيزيوكيمائية و الميكانيكية لعجائن مختلفة من الأسمنت المخلوط

$$
\text { دعاء عبد المنعم, مها ربيع, اية الله محمود ابر اهيم” فيم الكيمياء ـكلية البنات- جامعة عين شمس }
$$

تعثبر صناعة الاسمنت من اكثر الصناعات الملوثة للبيئة و ذلك لانبعاث ثانى اكسيد الكربون و تر اب الافران منها , و لذللك اتجهت الانظار الى استبدال جزء من الاسمنت ببعض الاضافات التى تعمل على تحسين الخواص الفيزيائية و الميكانيكية مثل

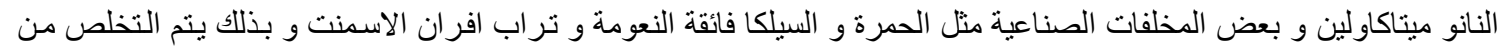
بعض المخلفات الضارة و تقليل كمية الاسمنت المستخدمة مما بساعد على توفير الطاقة المستخدمة و كذلك التقليل من تلوث البيئة . تهدف هذة الدراسة الى استبدال جزء من الاسمنت ببعض المخلفات الصناعية مثل الحمراو تراب الافران و السيلكا فائقة

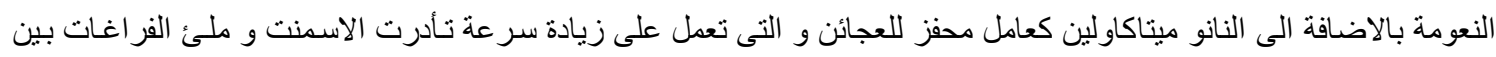

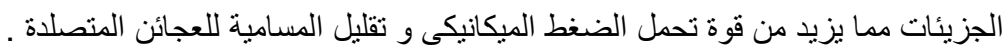
يمكن تلخيص اهم النتايج التى حصلنا عليها فى ما يلى :

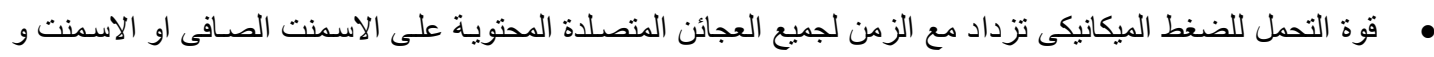

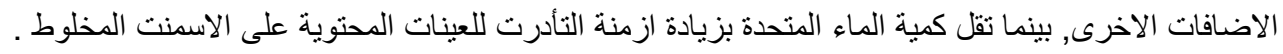

• تزداد قوة التحمل للضغط الميكانيكى للعينات المحتوية على نانوميتاكاولين حتى 8 \% عن عجائن الاسمنت الصافى.

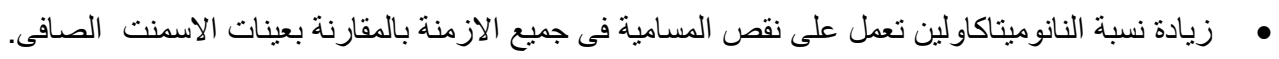

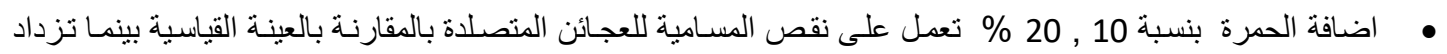
المسامية فى العينات المحتوية على 30 , 40 \% من الحمرة.

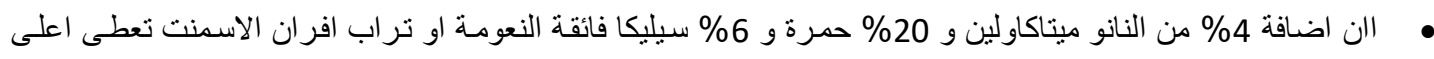
نتائج فى قوة التحمل للضغط الميكانيكى. 